\title{
REFERENCES
}

1. Burzik A. (2003). Üben im Flow: Eine ganzheitliche Übemethode. Infoblatt vom Musikschulkongress. HCC (Hannover Congress Centrum). Hannover [in German].

2. Guggenberger W. (2006). Basics Plus: Studien für 1-2 Blechblas instrumente im Violinschlüssel. Besetzung: 1-2 Trompeten. Rot an der Rot: Musikverlag Siegfried Rundel [in German].

3. Csikszentmihalyi M. (1990). Flow: The Psychology of Optimal Experience. New York: Harper and Row [in English].

4. Csikszentmihalyi M. (1996). Creativity: Flow and the Psychology of Discovery and Invention. New York: Harper Perennial [in English].

5. Csikszentmihalyi M. (1997). Finding Flow: The Psychology of Engagement With Everyday Life. New York: Basic Books [in English].

6. Loubriel L. (2009). Back to Basics for Trumpeters: The Teaching of Vincent Cichowicz. Chicago: Scholar Publications [in English].

7. Quinque R. (1980). ASAmethod. Bulle: Editions Bim [in German].

8. Quinque R.(1982). ASAtechnik. Bulle: Editions Bim [in German].

9. Quinque R.(1985). ASAknowhow. Bulle: Editions Bim [in German].

10. Quinque R.(1985). ASAjazz. Bulle: Editions Bim [in German].

11. Tomatis A. (2005). The Ear and the Voice. New York: Scarecrow Press, [in English].

12. Wolter E. (2012). Klangvitamin Musik: Musik the rapeutische Aspekte im Musik und Instrumentalunterricht. Kassel: Bosse. [inGerman].

Стаття надійшла до редакції 29.11.2017

УДК $78.03+786.8$

DOI 10.31723/2524-0447-2018-26-234-246

Володимир Георгійович Чефранов

https://orcid.org/0000-0003-1277-1112

в. о. доцента кафедри народних інструментів

Одеської національної музичної

академії ім. А. В. Нежданової

vonarfehc@gmail.com

\section{ЕЛЕКТРОННИЙ БАЯН У МУЗИЧНІЙ КУЛЬТУРІ: ІСТОРІЯ, ЕСТЕТИКА, ОРГАНОЛОГІЯ}

Мета роботи. У статті розглядаються історичні факти, естетичні i технологічні засади виникнення, модернізації та розповсюдження електронних інструментів, зокрема баяна. Методологія дослідження полягає в застосуванні компаративного, естетико-культурологічного, істо-

(C) Чефранов В. Г., 2018 
ричного, музикознавчого методів, які утворюють єдину методологічну основу. Зазначений методологічний підхід дозволяє розкрити та піддати аналізу специфіку електронних інструментів в ході історичної модернізації. Наукова новизна роботи полягає у виявленні значення електронного баяна у музичному мистецтві. Уточнюються історико-фактичні та техніко-органологічні параметри вказаного виду інструменталізму. Висновки. Концепція музично-інструментальних комп'ютерних технологій як нового явища в мистецтві відображає закономірності історичноі еволюції музичного інструментарію (процес прискорення зміни музичних стилів і творчих методів написання музики). Вказані конкретні переваги синтезування акустичної та електронної систем у баяні.

Ключові слова: електронні музичні інструменти, баян, електронний баян, органологія, модернізація музичного інструмента.

Chefranov Vladimir, and about. Associate Professor of the Department of National Instruments of Odessa National A. V. Nezhdanova Academy of Music

Electronic bayan (accordion) in musical culture: history, aesthetics, organology

The aim of the work. The article discusses historical facts, aesthetic and technological foundations of the emergence, modernization and distribution of electronic instruments, in particular, the accordion. The methodology of the study is the use of comparative, aesthetic-cultural, historical, musicological methods that form a single methodological basis. This methodological approach allows to reveal and analyze the specifics of electronic tools in the course of historical modernization. The scientific novelty of the work is to identify the value of the electronic accordion in the art of music. The historical and factual and technical-organological parameters of this type of instrumentalism. Conclusions. The concept of musical and instrumental computer technologies as a new phenomenon in art reflects the laws of the historical evolution of musical instruments (the process of accelerating changes in musical styles and creative methods of writing music). The specific advantages of synthesizing acoustic and electronic systems in the bayan are indicated.

Keywords: electronic musical instruments, button accordion, electronic button accordion, organology, modernization of a musical instrument.

Чефранов Владимир Георгиевич, и. о. доцента кафедры народных инструментов Одесской национальной музыкальной академии им. А. В. Неждановой

Электронный баян в музыкальной культуре: история, эстетика, органология

Цель работы. В статье рассматриваются исторические факты, эстетические и технологические основы возникновения, модернизации и распространения электронных инструментов, в частности баяна. Методология исследования заключается в применении сравнительного, 
эстетико-культурологического, исторического, музыковедческих методов, которые образуют единую методологическую основу. Указанный методологический подход позволяет раскрыть и подвергнуть анализу специфику электронных инструментов в ходе исторической модернизации. Научная новизна работы заключается в выявлении значения электронного баяна в музыкальном искусстве. Уточняются историкофактические и технико-органологические параметры указанного вида инструментализма. Выводы. Концепция музыкально-инструментальных компьютерных технологий как нового явления в искусстве отражает закономерности исторической эволюции музыкального инструментария (процесс ускорения изменения музыкальных стилей и творческих методов написания музыки). Указаны конкретные преимущества синтезирования акустической и электронной систем в баяне.

Ключевые слова: электронные музыкальные инструменты, баян, электронный баян, органология, модернизация музыкального инструмента.

Актуальність теми дослідження. У музичному побуті останніх десятиріч набуває розвитку та поширення новий клас електронних музичних інструментів, які стали одним із продуктів промислової, а втім - електронної, цифрової революції. Ці електронні інструменти стрімко удосконалюються сьогодні разом з розвитком комп’ютерних технологій. Адже швидкодія і технологічні можливості комп'ютера за останні два-три десятиріччя збільшилися в сотні тисяч разів. Це означає, що вже сьогодні широкому колу музикантів стають доступні пов’язані з цими процесами музичні інструменти, які відрізняються не просто значними виразовими ресурсами, а й абсолютно новими тембральними якостями. 3 їх допомогою досягаються оркестрова різнотембральна насиченість фактури, небувалі нові тембри і звуки, поліритмічні утворення, що сприяє жвавості композиторських і виконавських виходів. Синтезатори з фортепіанною клавіатурою сьогодні вже стають мало не дитячими іграшками.

Акустичний баян, модернізований до сучасного ємного у фактурно-артикуляційному відношенні, оркестроподібного вигляду трохи більше століття назад (від 1908), ще від патенту К. Деміана на «акордіон» 1829 року представляв собою перший у світі акустичний музичний «синтезатор» - механіка його лівої клавіатури передбачала поєднане звучання тризвучних (спочатку тільки мажорних) акордів у певному діапазоні при натисканні, з одночасним рухом міху, однієї кнопки (інший цікавий акустичний синтезатор - Батищ-Тон, винахід О. Батищева - комбінований інструмент, до якого увійшли баян; фортепіано з пневматичною приставкою і гумовими трубками, по- 
дача повітря в які управлялася лівою клавіатурою баяна; скрипка 3 колісним смичком і механічними пальцями, які керувалися повітрям вже від правої клавіатури баяна) [4].

Наступні модернізації самої гармоніки-баяна відбувалися шляхом збільшення діапазону обох клавіатур; додавання металевих голосів при відкритті одного клапана для змінення і зміцнення звучання, у тому числі за допомогою регістрів-перемикачів; розширення гармонічного акомпанементу за рахунок введення мінорних акордів, домінантових і зменшених септакордів. Але непорушним залишався синтезуючий принцип звучання кількох голосів на одну кнопку (клавішу). Запровадження у лівій клавіатурі так званої виборної (мелодійної, за типом «ліва як права») системи у чистому вигляді збереглося тільки на концертинах і бандонеонах, на баянах така система без можливості іiї переключення на «готову» (з акордами) «протрималася» з 1910 по 1930-ті роки і не стала розповсюдженою серед виконавської громади. До того ж від середини XIX століття і права клавіатура синтезувала, як правило, звучання кількох голосів «у розлив», у поєднанні прямої і ламаної дек; з верхньою чи нижньою октавою, квінтою.

Накладання на подібний акустичний «синтезатор» електронних засобів звуковидобування склало специфічний напрямок інструментального виконавства. Відзначимо, що управління багатими звуковими можливостями електронного баяна виявляється одночасно доступнішим, ніж гра на традиційних інструментах, і складнішим. 3 одного боку, масу технічних проблем (віртуозна побіжність, фактурні складнощі, збагачення акомпанементом та ударними) бере на себе електроніка, з іншого - управління midi-системою складає додаткові завдання й труднощі перемикання, поєднання, знання. Але, безперечно, надає безліч ще не оцінених і навіть невідомих переваг для композитора і виконавця. Усе це створює актуальність наукового дослідження вказаного напрямку музичної культури з музикознавчих і виконавських позицій.

Мета роботи складається у визначенні основних історико-фактичних, естетичних і технологічних засад виникнення, модернізації та розповсюдження електронних інструментів, зокрема баяна, як втілення принципово нового, перспективного засобу художнього втілення в аспекті актуального для плинної епохи пошуку «нового звуку» $[6,50]$.

Виклад основного матеріалу. Найперша згадка про «зустріч» музики і електрики (ще не електроніки) сягає 1761 року, коли Ж. де Лаборд 
отримав патент на «електричний» клавесин, механіку якого приводили в дію працюючі на гальванічних батареях електромагніти. У 1837 році К. Пейдж відкрив принцип електронного камертона. Е. Лоренц 1885 року запатентував метод звуковидобування за допомогою електромагніту. Але усе це ще не було пов'язаним з музикою як мистецтвом, працюючи на рівні наукових експериментів. Перший електромеханічний музичний інструмент, звучання якого почула публіка, створив американець Тадеуш Кахілл в 1906 (перший його винахід під назвою динамофон запатентований 1897) році з метою створення i поширення музики за допомогою електрики (своєрідне «схрещення» принципів генератора змінного струму і телефону). Інструмент отримав назву телармоніум (англ. Telharmonium), що складається 3 англійського слова telephone (телефон) і латинського harmonium (гармонія) і важив 200 тонн. На основі електричних генераторів і тональних коліс Кахілл відтворював різні ноти. Все контролювалося трьома зміненими активними органними клавіатурами. Втім велика міцність телармоніуму заважала роботі телефонних ліній, виконавці (їх мало бути двоє) скаржились на сторонні призвуки та й економічні питання не склалися. Тож у 1916 році інструмент замовк.

Однак уже в 1919 році російський винахідник Лев Сергійович Термен створив компактний терменвокс, яким до сих пір користуються деякі музиканти. Унікальність інструмента в тому, що управління звуком відбувається в результаті вільного переміщення рук виконавця в електромагнітному полі поблизу двох металевих антен. Зміна висоти звуку досягається шляхом наближення руки до правої антени, в той час як гучність звуку керується за рахунок наближення іншої руки до лівої антени. Страхітливі ефекти, звуки космосу, наближення чогось непізнаного - для цього застосовується терменвокс. Хічкок використовував його для запису саундтрека до фільмів «Птахи» і «Заворожений». Фрідріх Траутвайн у 1930-х роках конструює траутоніум - ящик 3 «ламповим генератором»: виникаючі в лампі електричні коливання, перетворювалися на звук. Наступним кроком став винахід інженера і власника компанії Л. Хаммонда. В результаті роботи цілого колективу вдалося змішати прості «фундаментальні» звуки з обертонами і контролювати гучність кожного з цих компонентів, що вплинуло на багатство і яскравість тону. 1934 року винахід було запатентовано, i органістка Луїза Бенке продемонструвала його. Електронний орган Хаммонда видавав 253 мільйони звуків, переміг у спорі за право називатися органом поряд з духовим інструментом і «оселився» по числен- 
них церквах і професійних рок-студіях: «Бітли» використовували його в альбомах «Rubber Soul», «The Beatles'68», «Abbey Road» i «Get Back», a «Pink Floyd» - в фінальній композиції «Echoes» 3 альбому «Meddle» (дивний звук, що «капає» на початку твору).

Зразок монтажу «електрозвуків» вперше був продемонстрований німецьким акустиком Боннського університету Вернером Майер-Епплером на Літніх курсах сучасної музики в Дармштадті в 1951 році, що викликало великий інтерес. Поряд з Центром електронної музики Боннського університету була створена Студія електронної музики при Кельнському радіо [5, 23-24]. Тут під художнім керівництвом композиторів і теоретиків Хер-Берта Аймерта і Карлхайнца Штокхаузена утворилася група ревних прихильників електроніки, до яких приєдналися потім Херман Хайс, Пауль Гредінгер, Анрі Пуссер, П'єр Булез. Друга хвиля авангарду стимулювала пошуки нових звукових засобів і в галузі електричних інструментів. А досягнення в сфері електроніки дали новий імпульс для появи і розвитку різних власне музичних творчих напрямків (електронної і конкретної музики). В кінці 1940-х - на початку 1950-х рр. електронна музика існувала в трьох напрямках, пов'язаних з естетикою видатних композиторів-авангардистів - П'єра Шеффера (суворий відбір переважно необроблених шумових звучань навколишньої дійсності - «конкретна музика», заснована на «використанні фіксованих звуків замість нотації» [2]); Карлхайнца Штокхаузена (музичні засоби і прийоми, які створюються виключно засобами електрики, звукового синтезу і не існують у природі); американська гілка - Володимир Усачевський і Отто Лайонінг - використовували оброблені звуки традиційних музичних інструментів.

В 1959 (ідея виникла 1938, але не одержала підтримки) Євген Мурзін сконструював перший у світі багатоголосий синтезатор, який отримав назву «АНС» («Александр Николаевич Скрябин» - через зв'язок видимого і звучного). Принцип дії заснований на оптичному записі звуку, використовуваного в кінематографі (фотопомножувач). У 1960-х у Москві відкривається Експериментальна студія електронної музики, де синтезатор «АНС» починають використовувати, працюючи над своїми музичними творами, С. Губайдуліна, А. Шнітке, Е. Артем’єв. У 1968 році Московська експериментальна студія електронної музики спільно з фірмою «Мелодія» випускають платівку «Космос» $з$ абсолютно новою для тих часів музикою за участю цього унікального синтезатора. Надалі на вдосконалення та розвиток елек- 
тронних музичних інструментів вплинув винахід транзистора. Синтезатори набули зручних для виконавця розмірів. Їх стали конструювати з окремих блоків. Тепер, використовуючи стандартні елементи, почали виготовляти інструменти, які володіли різними характеристиками [3].

У 1962 році в Італії інженером Паоло Кетоффом був винайдений синтезатор «Сінкет» для «живої» електронної музики. Інструмент мав три клавіатури, кожна керувала певними тонами. У 1964 роціз'явилися синтезатори американців Роберта Моуга (фортепіанна клавіатура, як для традиційної гри) і Дональда Бучлі (рухливі клавіші були замінені датчиками, які спрацьовували від дотику). Моуг заснував свою фірму. У 1968 році на його аналоговому синтезаторі Венді Карлос записав диск перекладень музики Й. С. Баха, який отримав премію Grammy і зробив Моуга відомим. У 1970 році на ринки вийшов його перший компактний синтезатор «Міні-Моуг». Незабаром синтезаторами Моуга захопилися провідні рок-групи того часу — «Бітлз», «Роллінг стоунз» $\mathrm{i}$ «Дорз». Незважаючи на те, що аналогові «Моуги» тепер можна знайти тільки в музеях, їх цифрові нащадки широко використовуються сучасними музикантами в самих різних жанрах. Сьогодні провідні світові фірми Yamaha, Casio, Korg, Roland, Kurzweil випускають синтезатори початкового, напівпрофесійного і професійного рівнів.

Усі описані інструменти мали органно-фортепіанні клавіатури, як втілення універсально-оркестрального типу мислення. Розвиток мікроелектроніки і поява інтегральних схем сильно вплинули на їх розвиток. Звучанням стали керувати за допомогою методів цифрового управління, та й сам звук змінився на цифровий вигляд. До вісімдесятих років в основному створювалися аналогові синтезатори. У них електричні коливання за своєю формою нагадували звукові хвилі акустичних інструментів. Синтезатори цифрові, а також цифрові музичні системи генерували серії чисел. Ці числа перетворювалися в електричні коливання і надходили в динаміки. Наприкінці вісімдесятих років комп'ютерна техніка об'єдналася з технологією цифрового запису звуку та цифрового синтезу в одну цілу систему. Музичні інструменти, виготовлені за цим принципом, отримали нову назву цифрові музичні робочі станції (із вбудованим секвенсером).

На сьогоднішній момент існують два напрямки поширення і розвитку інструментів цієї групи: MIDI (Musical Instrument Digital Interface)-інструменти (клавіатури) та електронні (цифрові) музичні інструменти. До кінця 1970-х років синтезатори представляли собою 
набори генераторів звукових частот, керованих напругою. Натискання клавіші на клавіатурі синтезатора включало генератор, частота якого задавалася напругою від регулятора тону цієї кнопки. Кількість окремих генераторів визначала кількість тонів синтезатора, які можуть звучати одночасно. Конкретні моделі синтезаторів могли мати власні особливості звучання і характерні тільки для них спеціальні ефекти. Реалізувати управління усім розмаїттям потенційних можливостей синтезу звуку в рамках одного аналогового пристрою було неможливо. Робоче місце музиканта, як правило, складалося з кількох різнорідних синтезаторів, кожен з яких міг генерувати тільки один спектр звукових коливань - управлятися з таким різноманіттям було надзвичайно складно. До початку 1980-х необхідність збільшення зручності та гнучкості управління різнорідними синтезаторами стала очевидною, а розвиток електроніки і подальша комп’ютеризація підказали шлях вирішення проблеми за допомогою цифрового програмного управління. Компаніям-виробникам вдалося домовитися про розробку і підтримку єдиного стандарту інтерфейсу (сукупність засобів, методів і правил взаємодії між елементами системи) управління синтезаторами, який і з'явився в 1982 році.

Вимога стандартизації передбачала поділ органів управління і пристроїв синтезу звуку. Інтерфейс MIDI фактично став засобом передачі положення клавіш і регуляторів від клавіатури до самого пристрою синтезування звуку. Відтепер музикант міг за допомогою лише однієї клавіатури управляти відразу декількома синтезаторами різних типів і виробників. Більше того, цифровий формат передачі дозволив доповнити апаратуру секвенсорами - пристроями, що запам'ятовують награну мелодію. Музикант міг записувати композиції або окремі їх частини, мікшувати їх без втрат якості звуку і використання складних студійних магнітофонів. Стандарт дуже швидко завоював ринок. Надалі ж, доповнюючи новими більш досконалими можливостями і опціями, він не втратив актуальності і в наш час.

Новим, самостійним напрямком в конструктивному розвитку баяна стало застосування в якості звукообразів начал електроніки. 3'явилися електронні баяни і акордеони. Зовні електронний баян схожий зі стандартним баяном з п’ятирядною правою і шестирядною лівою клавіатурами і грають на ньому музиканти-баяністи (хоча багато музикантів розглядають сам інструмент і виконавство на ньому за межами баянного мистецтва). I любителя музики, і досвідченого професіонала, що вперше потрапили на концерт виконавця на елек- 
тронному баяні (або акордеоні), все почуте і побачене просто приголомшує. Адже сучасний електронний баян - це, по суті, цілий оркестр в руках одного музиканта. Він володіє тисячами тембрів: від скрипки і гавайської гітари - до труби і клавесина, синтезує звучання струнної або будь-який інший групи інструментів, дозволяє на тлі багатоголосого оркестрового звучання виділити тембром і динамікою солюючий голос i, нарешті, має в якості акомпанементу електронну ритм-приставку, імітує гру на ударних інструментах. Все це відкриває перед виконавцем на електронному баяні воістину безмежні перспективи творчих пошуків.

У сучасній виконавській практиці MIDI-інструментом «язичкової» групи є сам інструмент (в його акустичному вигляді) зі вмонтованою у нього системою безконтактних датчиків, розташованих над клапанами всередині інструмента. На клапані закріплений магніт, який при наближенні до датчика змінює його параметри, відповідно до чого вищевказаний датчик повідомляє до звукового модулю (апаратний синтезатор) номер клавіші (кнопки) з присвоєним звуком i швидкість натискання відповідної клавіші (кнопки). Оскільки у звуковий модуль (синтезатор або комп'ютер) вкладено певний банк звуків, то «на виході» ми можемо мати безмежно широку палітру тембрів.

Усередині інструмента також розміщений датчик тиску повітря його завданням $є$ вимір зусилля, прикладеного до міху (можливість зміни сили звуку). Таким чином, система дозволяє доповнити звичайний акустичний баян (сам по собі оркестроподібний) функціями синтезатора, що значно розширює його тембральні і фактурні можливості.

Однак в силу того, що ця система передбачає наявність численного і дорогого устаткування (сам інструмент зі встановленою у нього MIDI-системою, звуковий модуль (найчастіше в його ролі виступає комп'ютер з відповідною програмою), підсилююче та акустичне обладнання (динаміки), популярність системи залишається не високою. Ця обставина послужила відправною точкою в розробці і створенні такого роду системи, в якій би всі перераховані вище складові були зосереджені в одному блоці (корпусі) з мінімальним залученням сторонніх (додаткових) аксесуарів. До того ж не всі достатньою мірою володіють баяном, фортепіано в цьому розумінні більш універсальне.

На початку 1960-х років в Житомирі на заводі «Електровимірювач» був створений перший в СРСР промисловий електромузичний інструмент «Естрадін» («Естрадний інструмент»), який отримав ім’я 
«Романтика». 1964 року конструкція була продемонстрована комісії, після чого щорічно 12 лютого на заводі відзначався День електромузики. До майстрів-інженерів Л. Федорчука, В. Волошина, Л. Фукса приєднався баяніст А. Грибер. До житомирського акустичного серійного баяну «Мрія» конструктори Леон Толчинський і Діма Шраєр розробили оригінальну контактну систему і панель перемикачів для управління електронними звуками, регістрами і ефектами у поєднанні зі звучанням звичайного баяна. Вдалося домогтися кришталевої чистоти звучання, що дозволило завдяки ефектам вібрато, тремоло, перкусії, реверберації, тембрового гліссандо і ритмічного супроводу відтворювати гру органа, рояля, інструментів оркестрів - весільного сільського, джазового або естрадного (1970р.).

Анатолій Бєляєв у 1964 році, будучи вже відомим концертуючим солістом Москонцерту, першим став грати на електронному баяні, не втрачаючи при цьому живого звучання інструмента, а з 1979 року на «Клавіні» (комбінація готово-виборного баяна з електронним органом, конструктори Ю. Волковіч і А. Явелов). Інструмент з кількома тисячами тембрів та їх поєднань, комбінацією електронних та акустичного (міхом) звучань, пам'яттю для вибору однією клавішею був виготовлений італійською фірмою «Форвіза», електроніка - Чикаго США. Наявність ножної педалі дозволяла не тільки регулювати динамічну гнучкість, але й створювати потрібний баланс між голосом і акомпанементом. У програмі були класика і естрада [1].

П'ятірядний електронний баян «Топаз» (Качканарський радіозавод «Форманта», 1970) призначений для імітації звучання традиційного баяна, застосовує реєстровий метод синтезу для створення звуків інших інструментів, синтезування тембрів та ін. Має вбудований гучномовець з регулюванням рівня, імітацію руху міха в лівій клавіатурі, педаль управління гучністю. Використовує параметри: частота тремоло, частота вібрато, глибина вібрато, настройка, баланс клавіатур, гучність, тембр ВЧ / НЧ, кнопки перемикання регістрів, вмичкач гучномовця, живлення.

П’ятирядний фірмовий італійський баян (кнопковий акордеон) легендарного італійця Paolo Soprani (модель Paolo III, C-гриф) - на відміну від слов'янського баяна B-Griff. Ця начебто невелика різниця - перший і третій ряди помінялися місцями - вимагає перенавчання для вітчизняних виконавців.

Цифровий баян (акордеон) Weltmeister оснащений унікальною midi-системою Blue line - найдосконалішою і надійною Midi- 
системою (до 4 Midi-каналів для дисканта), з поліпшеною динамікою міху, чутливою багаторівневою клавіатурою, зручним програмним забезпеченням з USB-кабелем для програмування.

Розробки компанії «Roland» на початку XXI століття в основному сфокусовані в двох областях - по-перше, це створення професійних цифрових музичних інструментів серії «V» (Virtual). В інструментах даної серії використовуються складні математичні моделі реальних фізичних процесів, що відбуваються всередині акустичних музичних інструментів. У серії випущені ударні установки (V-Drums), акордеони і баяни (V-Accordeon), фортепіано та роялі (V-Piano). Друга галузь розробки - створення універсальних інструментів та інших продуктів (в тому числі комп'ютерних програм, аксесуарів, програм для iPad i iPhone), орієнтованих на музикантів-аматорів і побутове застосування. Всесвітньо відомі виконавці Roland V-Accordion - Серджіо Скаппіні, Людовик Байєр, молоді - Олексій Черномордиков, Станіслав Малишев, одеський баяніст і майстер Іван Сєбов.

Московський баяніст Володимир Бутусов грає на електронних баянах італійської фірми Scandalli, «Юпітері» (московської фабрики Є. Гусарова), тульському «Тула» та ін. Сьогодні пропонує також взаємодію цифрового баяна (MIDI-системи) зі звуковим модулем Роланд BK7M, який здійснює автоакомпанемент, доповнюючи баянну акустику функціями синтезатора. Також пропонує створення на базі корпусу і механіки акустичного баяна (акордеона, навіть гармошки) створити потужний електронний інструмент, використовуючи нову вітчизняну MIDI-систему з семплами. Таку використовує і Айдар Гайнуллін - на італійському баяні Balloni Burini.

Висновки. Винахід і подальше поширення електрики, «оцифровування» навколишньої життя, а також композиторські пошуки «нового звуку» другої половини ХХ століття послужили відправними точками для винаходу і подальшого поширення електронних музичних інструментів. На сьогоднішній момент цей еволюційний шлях пройшли практично всі найпоширеніші акустичні музичні інструменти - від гітари, скрипки, духових, до фортепіано, органу, баяна. Таким чином, концепція музично-інструментальних комп'ютерних технологій як нового явища в мистецтві відображає закономірності історичної еволюції музичного інструментарію (процес прискорення зміни музичних стилів і творчих методів написання музики).

Завдяки своїй портативності, компактності клавіатур, багатотембровості, артикуляційній і динамічній гнучкості, фактурній 
оркестроподібності, здатності до сонорного різноманіття, іманентному вектору театралізації (в самій посадці, постановці, розгорнутості до слухача), генетичному корінні у масових жанрах баян у поєднанні з електронними можливостями (у тому числі комбінованої акустично-електронної форми) представляє неабияку творчу перспективу у сольній та оркестрово-ансамблевій якості. До вказаних можливостей акустичного інструмента вдало додаються: величезне, воістину невичерпне розмаїття тембрів, їх відтінків і комбінацій; здатність моделювати штучні акустичні ефекти різного роду приміщень (hall, room, plate і т. д.), можливість фіксації музичного тексту в вигляді послідовності музичних подій з відтворенням звукової палітри тембрального, метроритмічного, динамічного і т. п. музичних творів, можливість квантування ритмічного малюнка музичного тексту, яка полягає у вирівнюванні ритмічного малюнка мелодії або фактурного супроводу, конвертація MIDI-секвенції в нотний текст у вигляді клавіру, партитури, практично необмежена тривалість звучання.

\section{СПИСОК ЛІТЕРАТУРИ}

1. Басурманов А. Справочник баяниста. М.: Сов. композитор, 1987. 424 с.

2. Гарбузов Н. А. Зонная природа тонального слуха. М.; Л.: АН СССР, 1950. $143 \mathrm{c}$.

3. История электронной музыки - от телеграфа до синтезатора. URL: https://theoryandpractice.ru/posts/8738-micro-music (дата обращения 15.08.2017).

4. Мирек А. И звучит гармоника... М.: Советский композитор, 1979. 182 с.

5. Пучков С. В. Музыкальные компьютерные технологии как новый инструментарий современного творчества: дис. ... канд. искусств.: 17.00.09 / СПб. гуманит. ун-т профсоюзов. Санкт-Петербург, 2002. 186 с.

6. Теория современной композиции / отв. ред. В. С. Ценова. М.: Музыка, 2007. $624 \mathrm{c}$.

\section{REFERENCES}

1. Basurmanov, A. (1987). Reference book bayanist. M.: Owls. Composer [in Russian].

2. Garbuzov, N. A. (1950). Zonal nature of tonal hearing. M.; L.: USSR Academy of Sciences [in Russian].

3. The history of electronic music - from telegraph to synthesizer. URL: https:// theoryandpractice.ru/posts/8738-micro-music (appeal date 08/15/2017)

4. Mirek, A. K. (1979). And the harmonica sounds... M.: Soviet composer. [in Russian]. 
5. Puchkov, S. V. (2002). Musical computer technology as a new toolkit of modern creativity. Candidate's thesis. St. Petersburg: C-pb. humanity un-t trade unions. [in Russian].

6. Theory of modern composition (2007). Ed. ed. V. S. Cenova. M.: Music [in Russian].

Стаття надійщла до редакції 27.12.2017

УДК 784.58

DOI 10.31723/2524-0447-2018-26-246-255

Руденко Олександр Федорович

https://orcid.org/0000-0002-0368-6445

Викладач кафедри хорового диригування, вокалу та методики музичного навчання навчально-наукового інституту культури і мистецтв

Сумського державного педагогічного

університету ім. А. С. Макаренка sasha798132gmail.com

\section{УКРАЇНСЬКА ШКОЛА ВОКАЛЬНОГО МИСТЕЦТВА: ТРАДИЦІї ТА СУЧАСНІСТЬ}

Мета статті - дослідити основні віхи розвитку української вокальної школи, зокрема факти діяльності духовно розвинутих особистостей у докласичний та класичний період становлення українського вокального мистецтва. Наукова новизна роботи полягає у виявленні тенезу тогочасного вокального новаторства, що мала вплив на посткласичні тенденції розвитку мистецтва співу. Методи дослідження. Для досягнення зазначеної мети використано метод вивчення наукової літератури з досліджуваної проблеми та ретроспективний аналіз ідей музичного виконання у різні історичні періоди. Висновки. Навчання мистецтву співу, вивчення фактів традиційності та сучасності у розвитку практичних аспектів вокального навчання - це кропіткий, але необхідний процес, спрямований на формування, збереження та примноження самобутньої музичної національної культури.

Ключові слова: професійна музична освіта, традиції, сучасність вокальне навчання, спів, культура.

(C) Руденко О. Ф., 2018 